\title{
A PRELIMINARY INVESTIGATION OF HTR1A GENE EXPRESSION LEVELS IN AUTISM SPECTRUM DISORDERS
}

\author{
SHAYMAA M. YAHYA ${ }^{*}$, OLA GEBRIL ${ }^{2}$, EHAB R. ABDEL RAOUF ${ }^{2}$, MOHAMED E. ELHADIDY ${ }^{2}$ \\ 1Department of Hormones, Medical Research Division, National Research Centre, Giza, Egypt, ${ }^{2}$ Department of Research on Children with \\ Special Needs, Medical Research Division, National Research Centre, Giza, Egypt \\ Email: yahshay10@yahoo.com \\ Received: 15 May 2019 Revised and Accepted: 21 Jun 2019
}

\begin{abstract}
Objective: This study was conducted to explore the expression levels of HTR1A gene in a sample of Egyptian autistic children.

Methods: Thirty autistic patients (18 boys, 12 girls) and 20 controls were enrolled in the study. From each child, we isolated RNA samples from whole blood. Quantitative Real-Time PCR (qRT-PCR) was used to measure the gene expressions of HTR1A and normalized to the housekeeping gene, beta-actin.
\end{abstract}

Results: The HTR1A gene expression of healthy controls and ASD subjects were varied significantly ( $p=0.0062$ ). As compared to control of healthy subjects, the HTR1A expressions were greatly reduced in samples of ASD.

Conclusion: HTR1A gene expression level is a candidate gene for further studies to explore its potential roles in ASD related pathways.

Keywords: Autism spectrum disorders, Gene expressions, HTR1A gene expression

(C) 2019 The Authors. Published by Innovare Academic Sciences Pvt Ltd. This is an open-access article under the CC BY license (http://creativecommons.org/licenses/by/4.0/) DOI: http://dx.doi.org/10.22159/ijpps.2019v11i8.34141

\section{INTRODUCTION}

It is well established that a complex interaction between genetic epigenetic and environmental factors derives Autism's etiology. Chromosomal rearrangements at almost all chromosomes have been noticed among individuals with autism spectrum disorder (ASD) [1]. Unfortunately, little is known about the genetic variants and their contribution to the development of the ASD disorder. However, studying autistic related symptomatology may add to our knowledge about related genes and may help to further understanding of these disorders. For example, many serotonin polymorphisms were correlated with the level of IQ [2].

Various biological processes, besides, variations in gene expression levels between different biological tissues are implicated with ASD individuals. Moreover, some studies utilize gene expression analysis pattern to categorize autism into different subcategories. A list of genes found to be significantly dysregulated in ASD is needed to help further researchers to define any abnormalities useful for diagnosis or treatment [3].

The gene coding the 5 -HT1A receptor is $1.27 \mathrm{~kb}$ and intronless. It is located on the long arm of chromosome 5 . The family of G proteincoupled receptors (GPCRs) includes serotonin $1 \mathrm{~A}$ receptors which are involved in behavior, development and cognition [4]. Consequently, the serotonin $1 \mathrm{~A}$ receptor serves as an important target for neuropsychiatric disorders; for example; anxiety, depression and neuronal developmental defects [5].

High levels of serotonin in platelet were the first observation to relate 5 HT to ASD [6, 7]. In $25-50 \%$ of ASD patients, hyperferritinemia was observed [6]. In the prefrontal cortex, high concentrations of serotonin $1 \mathrm{~A}$ receptors are distributed. Due to its ability to reverse drug-induced cognitive deficits, HT1A receptor antagonists may be a good tool to cure age-related cognitive impairment [8]. The serotonin 5HT1A receptor has gained extensive investigations on their role in development, plasticity, and memory processes in the human brain [9].

HTR1A receptors are found as an auto receptor in the soma and dentrities of serotonergic neurons. And hence, reduction of the HTR1A autoreceptor activity results in an increase in serotonin transmission, suppress the function of target neurons mediated by HTR1A and results in a reduction in the potency of neural transmission [10]. Many transcriptional regulators of the 5-HT1A receptor have been identified [11].

The serotonin $1 \mathrm{~A}$ receptor, as well as, serotonin neurotransmitter system was extensively involved in the pathophysiology of mood and anxiety disorders. However, the researchers found that there is a variation in the genetic correlations [12]. Gross et al. [13] found that a varied pattern of up-regulated fear-related behaviors was showed by knock-out 5-HT1A receptor in mice.

Gene expression studies are helpful in the comparison between groups of subjects with ASD and healthy control samples in order to elucidate genes that are interrupted in the ASD group. And hence, this study was carried out to investigate HTR1A gene expression levels in ASD children. This also will be useful in increasing our knowledge about understanding autism development. Moreover, this will help in tailoring treatment strategies targeting the serotonergic system in the near future.

\section{MATERIALS AND METHODS}

\section{Patient selection}

This study was carried out on 30 children with autism (group I), their ages ranges between 6-13 y receiving care at NeuroRehabilitation Clinic, Center of Excellence of Medical Research, Department of Research on Children with Special Needs, Medical Division- National Research Centre. Group II included 20 normal children matched for age, sex and socioeconomic status with group I. The study was approved by the ethical committee of Medical research division, National Research Centre, approval number 18173. An informed consent was taken from each child's guardian.

\section{The inclusion criteria}

Diagnosed cases using 3 psychometric assessments; Diagnostic and Statistical Manual of Mental Disorders, Fourth Edition, Text Revision (DSM-IV), Childhood Autism Rating Scale (CARS) and Autism Diagnostic Interview-Revised (ADI-R). Their age range between 6-13 y,

\section{Exclusion criteria}

Cases received vitamins 3 mo before the study; Cases with auditory, vestibular, visual and respiratory defects; Cases with identified 
metabolic, genetic, or progressive neurological disorders, based on screening by clinical staff; and Secondary autistics with Genetic/ Medical conditions.

\section{Quantitative real-time gene expression analysis}

This was done using SensiFast ${ }^{\circledR}$ syberGreen one-step RT-PCR (Bioline). Briefly, total RNA was extracted from peripheral blood cells after RBC's lysis using Qiazole lysis reagent (Qiagen, USA) according to the manufacturer instructions. Primer sequence for $\beta$ actin gene is: Forward, CCTTCCTGGGCATGGAGTCCT; Reverse, GGAGCAATGATCTTGATCTTC; for HTR1A: Forward, GGCAACAACACCACATCACC, Reverse, and GACGGTCACGTCGGAGATAC. The copy numbers were normalized to 100,000 copies of the housekeeping beta-actin gene. The RT and subsequent PCR cycling conditions were as follows: $50^{\circ} \mathrm{C}$ for $10 \mathrm{~min}, 95^{\circ} \mathrm{C}$ for $5 \mathrm{~min}, 60^{\circ} \mathrm{C}$ for $30 \mathrm{~s}$ and then $95^{\circ} \mathrm{C}$ for $15 \mathrm{~s}$; the number of cycles were 40 cycles. BioRad Miniopticon ${ }^{\mathrm{TM}}$ real-time PCR cycler was used for quantitative estimation.

\section{Statistical analysis}

The data were analyzed using Microsoft Excel. All the data are expressed as mean \pm standard error mean. Analysis of the data was done using student $\mathrm{t}$-test to detect the significant difference between the studied groups. A level of $\mathrm{P}<0.05$ was defined as statistically significant. Data are represented as mean \pm sem.

\section{RESULTS}

In the study subjects, there were 18 males and 12 females ADS patients, besides, 10 females and 10 males' healthy controls. The average age ranged between $9.0 \pm 0.33$ in the patient group and $9.1 \pm 1.4$ in the control group. No significant differences were recorded between the groups for Gender $(\mathrm{P}=0.3,0.92$ for ADS patients and control, respectively) or age $(\mathrm{P}=0.98)$. HTR1A gene expression levels were normalized to 100000 copies of beta-actin. We found a high significant difference $(p=0.0062)$ in HTR1A gene expression between children suffering from ASD and healthy children group (table 1).

Table 1: The expression levels of HTR1A gene and demographic features of ADS patients and control group

\begin{tabular}{|c|c|c|c|}
\hline Variables & ASD $(n=30)$ & CONTROL $(n=20)$ & P value \\
\hline Age & $9.0 \pm 0.33$ & $9.1 \pm 1.4$ & 0.976426 \\
\hline \multicolumn{4}{|l|}{ Gender } \\
\hline Male & $8.8 \pm 4.4$ & $9.1 \pm 0.6$ & 0.3 \\
\hline Female & $9.4 \pm 0.5$ & $9.0 \pm 0.7$ & 0.92 \\
\hline HTR1A expression Levels (normalized Copy numbers) & $1950 \pm 395$ & $6468 \pm 1037$ & 0.0062 \\
\hline
\end{tabular}

Data are represented as mean \pm SEM

\section{DISCUSSION}

Zafeiriou et al. [6] suggested that in ASD, serotonin (5-HT) system have been disrupted. A variation in sequence in the serotonin genes is well-replicated leading to this disruption. Consequently, their involvement in the development of ASD has gained extensive studies [14]. The 5 HT1A receptors is considered as a molecular target for the action of serotonin [15]. In the current investigations, the gene expression levels of HTR1A gene were markedly reduced in ASD patients as compared to healthy controls. This finding is consistent with that of Sener et al., [11] who reported that the expression of HTR1A was undetectable in autistic Turkish children.

In the central nervous system, the rate-determining enzyme tryptophan hydroxylase 2 (TPH2) are secreted by the brain 5-HT system and evolves from neurons of the raphe nuclei [16]. In nonneuronal cells, the expression of 5-HT1A could be knocked down by a group of repressor elements in the upstream from the minimal promoter. Besides, in neuronal cell lines that express 5-HT1A receptors, the transcription of 5-HT1A could be down-regulated [17]. However, not all subcategories of neurons contain the 5-HT1A receptors, and consequently, more down regulators are needed to reduce its expression to exact neurons [18].

In the prefrontal cortex (PC), the main cause of the suppression of neuronal output by 5-HT1A receptors is the hyperpolarizing potassium current acceleration. Meanwhile, the output is mediated by 5-HT2A receptors through phospholipase induction [19]. Moreover, serotinin $1 \mathrm{~A}$ receptor agonists were reported to mediate the release of dopamine in the PC. Besides, it can moderate the effect of dopamine D2 receptor blockers on the secretion of dopamine [20]. Diaz-Mataix et al. [21, 22] reported that dopaminergic neurons in the ventral tegmental area could be potentiated by activation of PFC 5-HT1A receptors, and also the mesocortical release is accelerated by it.

The 5-HT1A autoreceptor signaling in raphe neurons was explored in previous work [23]. 5-HT1A was found to inhibit adenylyl cyclase activity, and hence negatively regulates serotonergic neuronal activity. The 5-HT1A autoreceptor chronic desensitization is needed to gain increased serotonergic neurotransmission [24] and to activate serotonin synthesis [25]. Building on this fact in humans, the 5-HT1A autoreceptors level is inversely associated with raphe 5HT formation in human [26].
When 5-HT1A auto receptor expression is increased, the activity of 5-HT neurons is suppressed. Meanwhile, an abolished behavioral response to 5-HT may be caused by suppressed post-synaptic 5HT1A receptors. Mental illness susceptibility is regulated by the receptor of 5-HT1A. However, further explorations for the exact pathway causing variable changes in the receptor of 5 -HT1A are needed [10].

Increasing in 5-HT neuron firing rate and accelerated 5-HT output were recorded in Mice with a $30 \%$ suppression in 5-HT1A auto receptors [27]. Endogenous 5-HT1A receptors were expressed in some neuronal cell lines. Particularly, the rat raphe RN46A cells which express the receptors of 5-HT1A. These cells are serotonergic and could be utilized as a model for 5-HT1A auto receptor handling [28].

\section{CONCLUSION}

This study concluded that the HTR1A gene expressions were greatly reduced in samples of ASD. This finding could suggest the importance of enrolling this gene in further studies in order to determine its exact role in ASD etiology.

\section{AUTHORS CONTRIBUTIONS}

Dr. Shaymaa MM Yahya: Conducting laboratory experiments, statistical analysis, Manuscript writing, and submission, Dr. Ola Gebril: Basic concept for research, physical examination and diagnosis of subjects, Prof Dr. Ehab Abdelraouf: physical examination and diagnosis of subjects, Dr. Mohamed E. Elhadidy: Conducting laboratory experiments, statistical analysis, Manuscript writing.

\section{CONFLICTS OF INTERESTS}

The authors declare that there is no conflict of interests.

\section{REFERENCES}

1. Haque S, Haque M. Art therapy and autism. Asian J Pharm Clin Res 2015;8:202-20.

2. Hervas A, Toma C, Romaris P, Ribases M, Salgado M, Bayes M, et al. The involvement of serotonin polymorphisms in autistic spectrum symptomatology. Psychiatric Genetics 2014;24: 158-63.

3. Vijayashankar S, Doss U, Damodaran LPM, Arumugam G Sridharan S. Analysis of salivary components to evaluate the 
pathogenesis of autism in children. Asian J Pharm Clin Res 2014;7:205-11.

4. Jafurulla MD, Bandar S, Pucadyil TJ, Chattopadhyay A. Sphingolipids modulate the function of human serotonin $1 \mathrm{~A}$ receptors: Insights from sphingolipid-deficient cells. Biochim Biophys Acta 2017;1859:598-4

5. Fiorino B, Severino E, Magli A, Ciano G, Caliendo Y, Santagada F, et al. 5-HT1A receptor: an old target as a new attractive tool in drug discovery from central nervous system to cancer. J Med Chem 2014;57:4407-26.

6. Zafeiriou DI, Ververi A, Vargiami E. The serotonergic system: its role in pathogenesis and early developmental treatment of autism. Curr Neuropharmacol 2009; 7:150-7.

7. Hammock E, Veenstra Vanderweele J, Yan Z, Kerr TM, Morris M, Anderso GM, et al. Examining autism spectrum disorders by biomarkers: an example from the oxytocin and serotonin systems. J Am Acad Child Adolesc Psychiatry 2012;51:712-21.

8. Misane I, Ogren SO. Selective 5-HT1A antagonists WAY 100635 and NAD-299 attenuate the impairment of passive avoidance caused by scopolamine in the rat. Neuropsychopharmacology 2003;28:253-64.

9. Whitaker Azmitia PM. Serotinin and brain development: role of in human developmental diseases. Brain Res Bull 2001;56:479-85.

10. Albert PR, LeFrancois B, Miller AM. Transcriptional dysregulation of 5-HT1A autoreceptors in mental illness. Molecular Brain 2011;4:21-35.

11. Sener EF, Uytun M, Bayramov KK, Zarasiz C, Oztop DB, Canatan $\mathrm{H}$, et al. The roles of CC2D1A and HTR1A gene expressions in autism spectrum disorders. Metab Brain Dis 2016;31:613-9.

12. Hettema JM, An SS, van den Oord EJCG, Neale MC, Kendler KS, Chen X. Association study between the serotonin 1A receptor HTR1A gene and neuroticism, major depression, and anxiety disorders. Am J Med Gen Neuropsychiatry Genet 2008;147B:661-6.

13. Gross C, Santarelli L, Brunner D, Zhuang X, Hen R. Altered fear circuits in 5-HT (1A) receptor KO mice. Biol Psychiatry 2000;48:1157-63.

14. Brune CW, Kim SJ, Leventhal BL, Lord C, Cook EH. 5-HTTLPR genotype-specific phenotypes in children and adolescents with autism. Am J Psychiatry 2006;163:2148-56.

15. Haddjeri N, Blier P, De Montigny C. Long-term antidepressant treatments result in tonic activation of forebrain 5HT1A receptors. J Neurosci 1998;18:10150-6.

16. Zhang X, Gainetdinov RP, Beaulieu JM, Sotnikova ID, Burch LH, Williams RB, et al. Loss of function mutation in tryptophan hydroxylase-2 identified in unipolar major depression. Neuron 2005;45:11-6.

17. Lemonde S, Rogaeva A, Albert PR. Cell type-dependent recruitment of trichostain A-sensitive repression of the human 5-HT1A receptor gene. Neurochem 2004;88:857-68.

18. Ou MX, Jafar Nejad H, Storring JM, Lemonde S, Albert FR. Novel dual repressor elements for neuronal cell-specific transcription of the rat 5-HT1A receptor gene. J Biol Chem 2000;275:8161-3.

19. Martin Ruiz R, Puig MV, Celada P, Shapiro DA, Roth BL, Mengod $\mathrm{G}$, et al. Control of serotonergic function in medial prefrontal cortex by serotonin-2A receptors through a glutamatedependent mechanism. J Neurosci 2001;21:9856-66.

20. Sakau M, Somboonthum P, Nishihara B, Koyama Y, Hashimoto $\mathrm{H}$, Baba A, et al. Postsynaptic 5-hydroxytryptamine (1A) receptor activation increases in vivo dopamine release in rat prefrontal cortex. J Pharmacol 2000;129:1028-34.

21. Diaz Mataix L, Scorza MC, Bortolozzi A, Toth M, Celada P, Artigas F. Involvement of 5-HT1A receptors in the prefrontal cortex in the modulation of dopaminergic activity: role in atypical antipsychotic action. J Neurosci 2005;25:10831-43.

22. Diaz Mataix L, Artigas F, Celada P. Activation of pyramidal cells in rat medial prefrontal cortex projecting to the ventral tegmental area by a 5-HT1A receptor agonist. Eur Neuropsychopharmacol 2006;16:288-96.

23. Polter AM. 5-HT1A receptor-regulated signal transduction pathways in brain. Cell Signal 2010;22:1406-12.

24. Albert PR, Lembo P, Storring JM, Charest A, Saucier C. The 5HT1A receptor: signaling desensitization and gene transcription. Neuropsychopharmacology 1996;14:19-25.

25. Berney A, Nishikawa M, Benkelfat C, Debonnel G, Diksrc M. An index of 5-HT synthesis changes during early antidepressant treatment alpha-Cmetyl-1-tryptophan PET study. Neurochem Int 2008;52:701-8.

26. Frey BN, Rosa Neto P, Lubarsky S, Diksic M. Correlation between serotonin synthesis and 5-HT1A receptor binding in the living human brain: a combined alpha- $\left[{ }^{11} \mathrm{CJMT}\right]$ and $\left[{ }^{18} \mathrm{~F}\right]$ MPPF position emission tomography study. Neuroimage 2008;42:850-7.

27. Richardson Jones JW, Craige CP, Guiard BP, Stephen A, Metzeger KL, Kung HF, et al. 5HT1A autoreceptor levels determine vulnerability to stress and response to antidepressants. Neuron 2010;65:40-52.

28. Storring JM, Charest A, Cheng P, Albert PR. TATA-driven transcriptional initiation and regulation of the rat serotonin 5HT1A receptor gene. Neurochem 1999;72:2238-47. 